\title{
THE EFFECT OF CONTACT HISTORY AND IMMUNIZATION STATUS ON THE NEW CASE OF LEPROSY
}

\section{Pengaruh Riwayat Kontak dan Status Imunisasi Terhadap Kasus Kusta Baru}

\author{
Ulfa Nurzila $^{1}$, Retno Adriyani ${ }^{2}$ \\ ${ }^{1}$ Public Health Faculty, Universitas Airlangga ulfa.nurzila-2016@fkm.unair.ac.id \\ ${ }^{2}$ Public Health Faculty, Universitas Airlangga, retnoadriyani@ fkm.unair.ac.id \\ Corresponding Author: Ulfa Nurzila, ulfa.nurzila-2016@fkm.unair.ac.id, Department of Environmental \\ Health, Public Health Faculty, Universitas Airlangga, Dr.Ir. H. Soekarno Street, Mulyorejo, Surabaya City, \\ East Java, Indonesia, Postal Code 60115
}

\section{ARTICLE INFO}

Article History:

Received December, $5^{\text {th }}, 2018$

Revised form January, $4^{\text {th }}, 2019$

Accepted January, 23 ${ }^{\text {rd }}, 2019$

Published online August, 30 ${ }^{\text {th }}, 2019$

\author{
Keywords: \\ leprosy; \\ characteristics; \\ immunization; \\ contact; \\ sumberglagah hospital
}

\section{Kata Kunci:}

kusta;

karakteristik;

imunisasi;

kontak;

rumah sakit sumberglagah

\begin{abstract}
Background: The highest new case of leprosy in Indonesia was occupied by East Java Province for four consecutive years, with the number of new leprosy patients as many as 3880 in 2017. Purpose: This study aims to determine the characteristics of individual factors and risks factor for new leprosy cases. Methods: This research is observational analytic research with case control research design. The population of the case is new lepers that were diagnosed since January-September 2018. Meanwhile, the control population is skin poli patients who have not been diagnosed with leprosy and tuberculosis. Sampling technique used was simple random sampling. Variables studied were individual characteristics (age, gender, income) and individual risk factors including immunization status, contact history and population status. Results: Majority of the $(57.90 \%)$ case respondents never received BCG immunization. $78.90 \%$ of the respondents case had history of contact with lepers before. $89.50 \%$ of respondents in cases and controls were permanent residents in Mojokerto Regency. Results of analysis of immunization status and contact history has significant influence to the new leprosy case. Status of not having $\mathrm{BCG}$ immunization $(\mathrm{OR}=5.16$; $95 \% \mathrm{CI}=$ $1.23<\mathrm{OR}<21.55), \mathrm{p}=0.04)$ and history of having contact with lepers $(\mathrm{OR}=6.43 ; 95 \% \mathrm{CI}=1,52<\mathrm{OR}<27.24), \mathrm{p}=0.02)$ significantly affected new cases leprosy. Conclusion: There is an influence between non-immunization status and history of contact with new leprosy cases. It is important to carry out early detection of individuals in contact with lepers, especially household contacts and recommendations for repeated BCG vaccination.
\end{abstract}

C2019 Jurnal Berkala Epidemiologi. Published by Universitas Airlangga.

This is an open access article under CC-BY-SA license (https://creativecommons.org/licenses/by-sa/4.0/)

\section{ABSTRAK}

Latar belakang: Kasus penderita kusta baru tertinggi di Indonesia ditempati oleh Provinsi Jawa Timur selama empat tahun berturut turut, dengan jumlah penderita kusta baru sebanyak 3880 orang pada tahun 2017. Tujuan: Penelitian ini bertujuan untuk mengetahui pengaruh karaktersitik dan faktor risiko individu terhadap kasus 


\begin{abstract}
kusta baru. Metode: Penelitian ini merupakan penelitian obervasional analitik dengan rancang penelitian case control. Populasi kasus adalah penderita kusta baru yang terdiagnosa sejak bulan Januari-September 2018, sedangkan populasi kontrol adalah pasien poli kulit yang tidak terdiagnosa penyakit kusta dan TBC. Teknik pengambilan sampel menggunakan simple random sampling. Varibel yang diteliti adalah karakteristik induvidu (umur, jenis kelamin, pendapatan) dan faktor risiko individu yang meliputi status imunisasi, riwayat kontak dan status kependudukan. Hasil: sebagian besar (57,90\%) responden kasus tidak pernah mendapatkan imunisasi BCG. Responden kasus 78,90\% memiliki riwayat kontak dengan penderita kusta sebelumnya. Responden kasus dan kontrol 89,50\% status penduduk tetap kabupaten Mojokerto. Hasil analisis status imunisasi dan riwayat kontak secara signifikan berpengaruh terhadap kasus kusta baru. Status tidak mendapatkan imunisasi BCG $(O R=5,16 ; 95 \% C I=1,23<O R<21,55), p=0,04)$ dan status pernah kontak $(O R=6,43 ; 95 \% C I=1,52<O R<27,24), p=0,02)$. Kesimpulan: Terdapat pengaruh antara status tidak imunisasi dan riwayat pernah kontak terhadap kasus kusta baru. Deteksi dini perlu dilakukan pada individu kontak dengan penderita kusta, terutama kontak serumah dan anjuran untuk vaksinasi BCG ulang.
\end{abstract}

(C2019 Jurnal Berkala Epidemiologi. Penerbit Universitas Airlangga. Jurnal ini dapat diakses secara terbuka dan memiliki lisensi CC-BY-SA (https://creativecommons.org/licenses/by-sa/4.0/)

\section{INTRODUCTION}

Leprosy does not only cause medical problems, leprosy also causes complex problems in aspects of people's lives. In the beginning of 2014,102 countries in 5 regions of the world reported the occurence of leprosy, namely Africa, America, Southeast Asia, the Middle East and the Western Pacific. WHO noted that Southeast Asia ranked first in the world's highest leprosy with an incidence of 215,656 people in September 2014 in Southeast Asia, especially countries in India, Brazil and Indonesia (Ministry of Health RI, 2018).

The Ministry of Health of the Republic of Indonesia places leprosy as the 10 most infectious diseases that are most prevalent in Indonesia. It has been able to achieve leprosy elimination status in 2000. However, despite achieving elimination status, the decline in the occurence of new leprosy is still relatively slow (Ministry of Health RI, 2012). In 2017, there were 10.477 patients of leprosy from 34 provinces. The number has decreased from the previous year which was 16.826. One of the provinces with the highest number of new cases of leprosy is East Java, which is 3880 new cases with a prevalence rate of 0.90 per 10,000 population in the year (East Java Provincial Health Office, 2018).
Figure 1 showed that although the number of new leprosy patients in East Java Province is the highest in Indonesia, this number has decreased significantly for four consecutive years, especially in 2017. In 2017, East Java also managed to reduce the prevalence of leprosy sufferers (East Java Provincial Health Office, 2018).

East Java Province has achieved leprosy elimination status in 2017 with a prevalence rate of less than 1 per 10,000 population. Early case of finding and providing quality leprosy services is a strategy for national leprosy control. The seriousness of the East Java Health Office to eradicate leprosy is proven by the existence of superior health facilities that have leprosy services, namely Sumberglagah Leprosy Hospital. This hospital fosters 20 cities / regencies in East Java which are included in high leprosy endemic areas, with cases > 30 cases per year (East Java Provincial Health Office, 2018).

Mojokerto Regency is one of 20 cities / districts assisted by Sumberglagah Leprosy Hospital to control leprosy. Figure 1 shows the case of new leprosy in Mojokerto Regency which was fluctuated where the highest cases occurred in 2015. The prevalence of leprosy in Mojokerto Regency in 2016 was 0.56 per 10,000 population. When it is compared to other cities / districts on Madura Island, the prevalence rate is smaller. 
The prevalence of Mojokerto Regency has increased from 2015, which is 0.37 per 10,000 population. Data from the health office states that the level 2 record rate in new leprosy cases is still $>5 \%$ in 2016 , which is $8.57 \%$. Disability rates of more than $5 \%$ prove the success of the case of finding strategy as early as possible as a leprosy control effort (East Java Provincial Health Office, 2018).

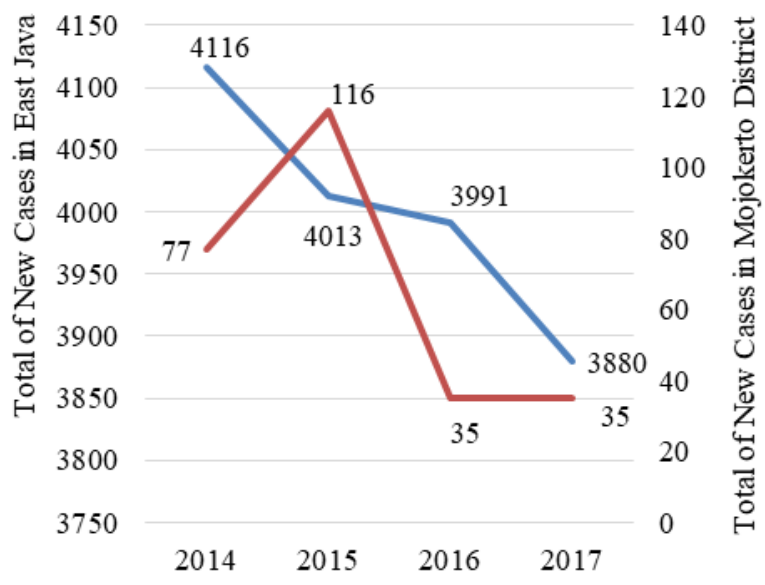

Provinsi Jawa Timur $\longrightarrow$ Kabutapen Mojokerto

Sumber: East Java Provincial Health Office, 2018

Figure 1. Total of New Cases in East Java Province and Mojokerto District at 2014-2017

According to Muharry (2014) it is explained that there are several factors that become the risk of leprosy. The risk factors are economic conditions, personal hygiene, knowledge, contact history and physical environment. Susanti \& Azam (2016) explained that immunization status, contact history and length of contact were risk factors for leprosy in Pekalongan city in 2013. The discovery of new patients by recognizing risk factors for someone affected by leprosy could help finding cases as early as possible. This study aims to determine the effect of immunization status and contact history on new cases of leprosy.

\section{METHODS}

$\mathrm{T}$ This type of research is an observational analytic study with a case control research design. The study was conducted on the patients of Mojokerto Regency in Sumberglagah Leprosy Hospital for 2 weeks, precisely on October 22 November 3, 2018. The population of in this study was leprosy patients that were newly diagnosed and recorded in the medical record of
Sumberglagah Leprosy Hospital in January to September 2018. The control population in this study was patients who visited dermatologist polyclinic that were not diagnosed with leprosy and tuberculosis in January-September 2018. Based on data obtained from the Sumberglagah Leprosy Hospital, the sample size was 19 people. Comparison of the number of case and control samples was 1: 1 . Thus, the overall sample size was 38 people, with the matching criteria of age, sex and residence in Mojokerto district.

The variables evaluated in the study were new cases of leprosy, both multibailer and papibacillary types as dependent variables, and as independent variables were individual characteristics including age, sex, income in months and individual risk. The factor variables included immunization status, contact history and population status. Age variables are divided into three categories, namely the age group of adolescents (12-25 years), adults (26-45 years), and the elderly (46-65 years). Monthly income refers to the minimum regional wage of Mojokerto Regency, which is Rp. $3,565,660.82$. Immunization status variables were ascertained with a scar on the right hand of the respondent. The population status variable is proven by ownership of the Mojokerto Regency Identity Card (KTP).

The primary data collection technique is done through interviews using a questionnaire by visiting the respondent's residence directly or meeting at the hospital. Secondary data regarding patients diagnosed with leprosy and non-leprosy were obtained from the medical records of the Sumberglagah Hospital. Data analysis was performed using the chi square test to see the influence of independent variables including characteristics (age, gender and income) and individual risk factors (immunization status, contact history and population status) on the dependent variable, using $\alpha=5 \%$.

\section{RESULTS}

\section{Characteristics of Respondent}

The majority of respondents in the case and control groups were adult $(47.40 \%)$, followed by the age group of the elderly $(36.80 \%)$, and the teenage group $(15.80 \%)$. The results of the chi square test statistical analysis obtained $\mathrm{p}$ value of $1.00>0.05$. Most of the respondents of case and control groups were male $(73.70 \%)$. The similarity of the number of respondents in the age group and gender is the matching criteria of the case and control groups. The results of the chi square 
statistical test analysis on sex variables obtained $\mathrm{p}$ values of $1.00>0.05$ (Table 1).

Most of the respondents have income below the minimum regional wage in Mojokerto Regency. In the case group, $63.20 \%$ of respondents earn below the minimum regional wage of Mojokerto Regency. In the control group, $52.60 \%$ of respondents earn below the minimum regional wage of Mojokerto Regency. The results of the statistical analysis obtained a $p$ value of 0.74 $>0.05$ (Table 1).

\section{Individual Risk Factors}

The respondent's immunization status variable was proven by the presence or absence of scar marks on the respondent's right arm. In the case group, the majority of respondents never did or received BCG immunization (57.90\%). In the control group, almost all respondents had done or received BCG immunization when they were children $(78.90 \%)$. The results of statistical analysis using the chi square test obtained a $\mathrm{p}$ value of $0.04<0.05$ with an $O R$ value of 5.16 (Table 2). This means that people who do not get BCG immunization are at risk of suffering from leprosy 5 times greater than those who get BCG immunization.

Almost all respondents in the case group had contact with lepers beforehand (78.90\%). Most of the respondents in the control group had never been in contact with lepers before $(63.20 \%)$. Most of the respondents in the case group contacted people with leprosy the last time were more than 2 years ago. Meanwhile, in the control group, most of them had contact with people affected by leprosy less than 2 years ago. The chi square statistical test results of contact history with leprosy events obtained a $\mathrm{p}$ value of $0.02<0.05$ with an OR value of 6.43 (Table 2). This means that people who have had contact with leprosy patients have a 6 times greater risk of developing leprosy than those who have never had contact with lepers.

Almost all respondents in both case and control groups were residents who settled in Mojokerto Regency $(89.50 \%)$ while the remaining $10.50 \%$ were not permanent residents of Mojokerto Regency. The results of statistical tests on population status variables obtained $p$ values of $1.00>0.05$ (Table 2).

\section{DISCUSSION}

\section{Characteristics of Respondent}

The results of the analysis showed no influence between the age of the respondent and the new leprosy case. This result is in line with the research conducted by Ratnawati (2016) which shows that there is no significant influence between age and the incidence of leprosy. Other studies conducted in the working area of Gunem and Sarang Health Center also showed that there was no influence between age and the incidence of leprosy (Yuniarsari, 2014). Wicaksono, Faisya, \& Budi (2015) also stated that there was no influence between age and leprosy.

Chronic diseases such as leprosy, the prevalence of diseases based on age groups does not show the risk of certain age groups to be infected with leprosy. Leprosy can occur at any age between infants to the elderly (Ministry of Health RI, 2012). The discovery of leprosy cases in children and adolescents shows active bacillus circulation which allows transmission to the healthy people and the failure of the health system to control leprosy (Oliveira \& Diniz, 2016).

Table 1

Distribution of Individual Characteristics in Mojokerto Regency in 2018

\begin{tabular}{|c|c|c|c|c|c|}
\hline \multirow{2}{*}{ Characteristics } & \multicolumn{2}{|c|}{ Case } & \multicolumn{2}{|c|}{ Control } & \multirow{2}{*}{$p$} \\
\hline & $\mathrm{n}$ & $\%$ & $\mathrm{n}$ & $\%$ & \\
\hline \multicolumn{6}{|l|}{ Age (year) } \\
\hline 12-25 (Adolescent) & 3 & 15,80 & 3 & 15,80 & 1,00 \\
\hline $26-45$ (Adult) & 9 & 47,40 & 9 & 47,40 & \\
\hline 46-65 (Elderly) & 7 & 36,80 & 7 & 36,80 & \\
\hline \multicolumn{6}{|l|}{ Sex } \\
\hline Man & 14 & 73,70 & 14 & 73,70 & 1,00 \\
\hline Woman & 5 & 26,30 & 5 & 26,30 & \\
\hline \multicolumn{6}{|l|}{ Income } \\
\hline$<$ District Minimum Wages (UMK) & 12 & 63,20 & 10 & 52,60 & 0,74 \\
\hline$\geq$ District Minimum Wages (UMK) & 7 & 36,80 & 9 & 47,40 & \\
\hline Total & 19 & 100,00 & 19 & 100,00 & \\
\hline
\end{tabular}


Table 2

Individual Risk Frequency Distribution in Mojokerto Regency in 2018

\begin{tabular}{lcccccccc}
\hline \multicolumn{1}{c}{ Individual Risk Factors } & \multicolumn{2}{c}{ Case } & \multicolumn{2}{c}{ Control } & \multirow{2}{*}{ OR } & \multirow{2}{*}{$95 \% \mathrm{CI}$} \\
\cline { 2 - 5 } & $\mathrm{n}$ & $\%$ & $\mathrm{n}$ & $\%$ & & & \\
\hline Imunization Status & 11 & 57,90 & 4 & 21,10 & 0,04 & 5,16 & $1,23-21,55$ \\
$\quad$ Never & 8 & 42,10 & 15 & 78,90 & & & \\
$\quad$ Yes, ever & 15 & 78,90 & 7 & 36,80 & 0,02 & 6,43 & $1,52-27,24$ \\
$\quad$ Contact History & 4 & 21,10 & 12 & 63,20 & & & \\
$\quad$ Ever & & & & & & & \\
$\quad$ Never & 2 & 10,50 & 2 & 10,50 & 1,00 & & \\
$\quad$ Population Status & 17 & 89,50 & 17 & 89,50 & & & \\
$\quad$ Imigrant & 19 & 100,00 & 19 & 100,00 & & & \\
$\quad$ Settle & & & & &
\end{tabular}

In this study, it was shown that there was no influence between gender and new cases of leprosy. This result is in line with the research conducted by Wicaksono, Faisya, \& Budi (2015) who suggested that there was no influence between sexes and clinical leprosy in Bandar Lampung gender 2015 with a $p$ value of 0.64 which was obtained using the chi square analysis test. The results of the same research were also disclosed by Muharry (2014) which was conducted in Tirto sub-district of Pekalongan regency regarding the risk factors for leprosy. The results of the chi square test obtained a $\mathrm{p}$ value of 0.70 , which means there was no influence between gender and the incidence of leprosy.

Research conducted by Ratnawati (2016) also showed similar results that there was no influence between gender and the incidence of leprosy in Bringin Sub-district, Ngawi Regency. This is because the proportion of gender in the case group and control group is the same, which is the matching criteria of the two groups of respondents. In the case group which was people affected by leprosy, the male respondents suffered from leprosy more compared to women. Men do more activities outside home which makes it possible to meet various kinds of people and places that are not necessarily free from the causes of leprosy.

Research conducted by Efrizal, Lazuardi, \& Seobono (2016) shows that the number of male $(67.86 \%)$ affected by lepers is greater than female ones. According to Silva et al (2018) in his research carried out in the City of Buriticupu, Maranhao, Brazil, an area considered a hyperendemic leprosy, stated that the majority of individuals affected by leprosy were male at $65.90 \%$.

The prevalence of leprosy on male is higher than that of women. Men are more at risk of leprosy due to their high mobility. This can increase the possibility of contact with at-risk populations (Thakkar \& Patel, 2014). The clinical development of leprosy requires a long incubation period and a complex system of host-pathogen interactions which is in individuals who are in productive age and have broad social interactions, especially male individuals who have high mobilization (Silva et al., 2018).

The results of this study indicate that there is no influence between income towards new leprosy cases. This result is not in line with the research conducted by Ratnawati (2016) in Bringin District, Ngawi Regency, which revealed that there was an influence between income and leprosy with the $\mathrm{p}$ value obtained was $0.03<0.05$. Muharry (2014) also explained in his research that based on the results of the chi square statistical test, the $\mathrm{p}$ value was $0.01<0.05$. It can be concluded that there is an influence between the economic conditions of the family and the incidence of leprosy. On the variable of family economic conditions, Muharry categorizes it into 2 , namely the low category (income <Rp. 565,000) and the high category (income> 565,000). Research conducted by Nurcahyati \& Wibowo (2016) in Konang and Geger Subdistrict, Bangkalan Regency, shows that almost all case respondents of lepers $(78.20 \%)$ have income $<$ Rp. 500,000. Both studies show that income $<\mathrm{Rp}$. 500,000 is a risk factor for leprosy. In this study, the income variable is categorized based on the Regency / City Minimum Wage which is set by the East Java governor and almost all respondents, both the case group and the control group, have less income than the regional minimum wage set by the government. Santos, Penna, Costa, Natividade, \& Teixeira (2016) show that leprosy is considered endemic in some countries with low economic and social levels, 
especially in India and Brazil. Income levels as one of a person's socio-economic indicators can also be a risk factor for leprosy.

The link between high income and health is based on opinions on health care, especially in terms of health services. Low-income communities have difficulty to access health services at health centers or hospitals due to other costs incurred such as transportation and other costs while undergoing treatment that must be paid. Financial problems are still the reason for obtaining health services even though the government has provided subsidies for free treatment in the form of a national health insurance program (Napirah, Rahman, \& Tony, 2016).

\section{Influence of Risk Factors on New Leprosy Cases}

This study showed that there is an influence between immunization status and leprosy case. The results of analysis showed that the OR value = 5,16 which shows that people who did not get BCG immunization had a risk of 5.16 times to be infected with leprosy compared to those who received $\mathrm{BCG}$ immunization.

This result is in line with the results of the research conducted by Susanti \& Azam (2016) in Pekalongan City which stated that someone who did not have a BCG vaccination status was 3.83 times more likely to be infected with leprosy than those who had BCG vaccination. Research that conducted by Aprizal, Lazuardi, \& Soebono (2017) in Lamongan Regency shows that the presence of scar after receiving BCG immunization affects the incidence of leprosy. Children with the scars after BCG vaccination will be protected from leprosy.

Research that is conducted by Richardus et al (2015) in Bangladesh showed that patients who had contact with lepers and who had received BCG vaccination showed clinical symptoms of $\mathrm{PB}$ leprosy within 12 weeks, while prolonged (1-2 years) contacts showed symptoms of MB leprosy. Research in Malawi states that giving a single dose of BCG vaccination can provide $50 \%$ protection and giving two doses can provide protection against leprosy up to $80 \%$ (Ministry of Health RI, 2012). The presence of scars after BCG vaccination is not only a marker for immunity to leprosy but also shows a higher risk of tuberculoid leprosy (Richardus et al., 2018).

The BCG vaccine is derived from the attenuated Mycobacterium bovis strain which is used as a living vaccine against tuberculosis (TB). The use of BCG as a vaccine against leprosy has not been officially recommended, but many countries with high number of cases provide repeated vaccination to adolescents and at-risk adults. The use of BCG vaccine against Mycobacterium leprae is based on the same genus between the causes of leprosy and attenuated vaccines. Mycobacterium leprae type bacteria have not been cultured in the laboratory until now (WHO, 2017).

In countries or regions with high incidence of $\mathrm{TB}$ and leprosy, one dose of BCG vaccine must be given to neonates at birth, or as soon as possible after birth, for prevention of TB and leprosy. If it cannot be given at birth, it must be given at the earliest opportunity and may not be postponed. Delay in vaccination can cause opportunities for exposure to TB or contacts infected with leprosy (WHO, 2017).

This study shows an influence between contact history for new cases of leprosy. The results of other studies conducted by Susanti \& Azam (2016) suggested that there was an influence between the history of contact with the incidence of leprosy in Pekalongan city. Contact with people affected by leprosy enables the transmission of Mycobacterium leprae from sick people to healthy people. Bacteria of patients who are not treated or irregularly treated are the main source of transmission. Therefore, it is important that there is an understanding and knowledge of the community about leprosy which is expected to increase public awareness of treatment and adhere to the instructions of health personnel.

Research that is conducted by Dabrera, Tillekeratne, Fernando, Kasturiaratchi, \& Østbye (2016) in Sri Lanka shows that there is an influence between house contact of lepers and a diagnosis of leprosy. Similar results also occur in research conducted by Fahik, Wahjoedi, \& Supardi (2014) in Belu District, which explained that most lepers had a history of contact with leprosy patients, namely, having lived together with lepers, sleeping in a room with lepers and changing clothes with lepers due to their kinship.

Research that is conducted by Tarmisi, Arifuddin, \& Herawanto (2016) shows that the contact history is a risk factor that has a direct effect on the incidence of leprosy in the Village of Air Panas, West Parigi District. The study conducted in Gujarat India stated that out of 250 respondents of lepers, $8.30 \%$ of them had a contact history of family and environment (Thakkar \& Patel, 2014). Research conducted by Feenstra, Nahar, Pahan, Oskam, \& Richardus (2013) showed that household contact has an influence 
with clinical leprosy with an OR value of 1.09. Contacts in the nearest environment are also associated with clinical leprosy with an OR value of 1.07. Mycobacterium leprae is the most easily spread bacteria in the household of an infected person. In endemic areas, social contacts in the closest environment of the patient, village or city environment, can also be a risk of leprosy transmission.

Gama et al (2018) states that individuals who are at home with lepers have a higher risk of being infected with leprosy. This is because they live close to the source of transmission. The possibility of transmission of the disease still exists even though the leper has received treatment. Leprosy is associated with close family contact and contact with leprosy in the social environment, which identifies contact exposure as the main determinant of leprosy transmission (Feenstra, Nahar, Pahan, Oskam, \& Richardus, 2013). The possibility of transmission through the respiratory tract is increasing where the respiratory tract is one of the portals of exit Mycobacterium leprae. The respiratory tract is also the location with many discoveries of this type of bacteria, so that transmission through this channel is considered to be the greatest risk of transmitting leprosy (WHO, 2016).

This research proves that there is no influence between population status and new leprosy cases. The results of the absence of influence between population status and the incidence of leprosy are likely because some of the respondents who settled and migrants in the case and control groups had the same magnitude in this study. This is contrary to the research conducted by Murto et al (2013) which shows that migration is a risk factor for leprosy. Transfer of population from an area that is endemic to non-endemic areas is one of the risk factors for leprosy. The lifestyles of the suburban population in terms of social, economical, behavior and unhealthy environment can affect the incidence of leprosy.

The prevalence of leprosy in a population can generally be donated through new cases and immigration cases. In immigration cases from endemic areas, especially areas that have difficulty in accessing health services for the treatment, leprosy can be a source of transmission of Mycobacterium leprae to other healthy people (WHO, 2016). This underlies the need for control of patients from an area so that leprosy is not spread in other areas.

\section{CONCLUSION}

There is an influence between immunization status and history of contact with new leprosy cases. Those who did not get BCG immunization and had contact with leprosy patients were more at risk of contracting leprosy compared to those who received BCG immunization. Control measures can be carried out by early detection of groups in contact with leprosy patients, especially at home contact. There is a need to increase awareness of the importance of BCG immunization to prevent leprosy. In some cases, the provision of repeated $\mathrm{BCG}$ vaccination is allowed to provide protection against leprosy, even though WHO does not recommend it.

\section{ACKNOWLEDGEMENT}

Thank you to the head of the Sumberglagah Leprosy Hospital and chairman of the research field at Sumberglagah Leprosy Hospital who gave permission and provided the data used in this study.

\section{REFERENCES}

Aprizal, Lazuardi, L., \& Soebono, H. (2017). Risk factors for leprosy in Lamongan Regency. Berita Kedokteran Masyarakat, 33(9), 427432.

Dabrera, T. M. E., Tillekeratne, L. G., Fernando, M. S. N., Kasturiaratchi, S. T. K., \& Østbye, T. (2016). Prevalence and correlates of leprosy in a high-risk community setting in Sri Lanka. Asia Pacific Journal of Publlic Health, 28(7), 586-591. https://doi.org/10.1177/1010539516666360

East Java Provincial Health Office. (2018). Health profile of East Java Province at 2017. East Java Provincial Health Office. Surabaya City.

Efrizal, E., Lazuardi, L., \& Seobono, H. (2016). Risk factors and distribution patterns of leprosy in Yogyakarta. Berita Kedokteran Masyarakat, 32(10), 347-352.

Fahik, A., Wahjoedi, I., \& Supardi, F. (2014). The prevalence of papibacillary and multibacillary leprosy is based on characteristics of occupancy density, contact history, socio-economic in Belu Regency, East Nusa Tenggara Province. Jurnal Kesehatan Masyarakat, 7(1), 155-160.

Feenstra, S. G., Nahar, Q., Pahan, D., Oskam, L., \& Richardus, J. H. (2013). Social contact patterns and leprosy disease : a case-control 
study in Bangladesh. Epidemiology and Infection, 141(3), 573-581. https://doi.org/10.1017/S0950268812000969

Gama, R. S., Gomides, T. A. R., Gama, C. F. M., Moreira, S. J. M., de Neves Manta, F. S., de Oliveira, L. B. P., ... \& de Oliveira Fraga, L. A. (2018). High frequency of M. leprae DNA detection in asymptomatic household contacts. BMC Infectious Diseases, 18(1), 16. https://doi.org/10.1186/s12879-018-30562

Ministry of Health RI. (2012). National guidelines for leprosy control programs. Jakarta: Ministry of Health RI.

Ministry of Health RI. (2018). Remove stigma and discrimination against leprosy. Jakarta: Ministry of Health RI.

Muharry, A. (2014). Risk factors for leprosy. Jurnal Kesehatan Masyarakat, 9(2), 174182.

Murto, C., Chammartin, F., Schwarz, K., da Costa, L. M. M., Kaplan, C., \& Heukelbach, J. (2013). Patterns of migration and risks associated with leprosy among migrants in Maranhão, Brazil. PLoS Neglected Tropical Diseases, $\quad 7(9)$, e2422. https://doi.org/10.1371/journal.pntd.0002422

Napirah, M. R., Rahman, A., \& Tony, A. (2016). Factors that related to the utilization of health services in the working area of Tambarana Community Health Center, Poso Pesisir Utara District, Poso District. Jurnal Pengembangan Kota, 4(1), 29-39.

Nurcahyati, S., N, H. B., \& Wibowo, A. (2016). The distribution of new leprosy cases is based on environmental and socio-economic factors in Konang and Geger Districts, Bangkalan Regency. Jurnal Wiyata, 3(1), 92-99.

Oliveira, M. B. B. De, \& Diniz, L. M. (2016). Leprosy among children under 15 years of age: literature review. Anais Brasileiros de Dermatologia, 91(2), 196-203. http://dx.doi.org/10.1590/abd18064841.20163661

Ratnawati, R. (2016). Factors related to the risk of leprosy (morbus hansen). 2-TRIK: Tunas_Tunas Riset Kesehatan, 6(3), 103109.

Richardus, R. A., Butlin, C. R., Alam, K., Kundu, K., Geluk, A., \& Hendrik, J. (2015). Clinical manifestations of leprosy after bcg vaccination: an observational study in Bangladesh. Vaccine, 33(13), 1562-1567. https://doi.org/10.1016/j.vaccine.2015.02.017
Richardus, R., van Hooij, A., van den Eeden, S. J., Wilson, L., Alam, K., Richardus, J. H., \& Geluk, A. (2018). BCG and adverse events in the context of leprosy. Frontiers In Immunology, 9(629), 1-11. https://doi.org/10.3389/fimmu.2018.00629

Santos, S. D., Penna, G. O., Costa, M. D. C. N., Natividade, M. S., \& Teixeira, M. G. (2016). Leprosy in children and adolescents under 15 years old in an urban centre in Brazil. Memórias do Instituto Oswaldo Cruz, 111(6), 359-364. http://dx.doi.org/10.1590/007402760160002

Silva, A. R. D., Lima Neto, P. M., Santos, L. H. D., Lima, R. J. C. P., Tauil, P. L., \& Gonçalves, E. D. G. D. R. (2018). Factors associated with leprosy in a municipality of the Pre-Amazon region, state of Maranhão, Brazil. Revista da Sociedade Brasileira de Medicina Tropical, 51(6), 789-794. http://dx.doi.org/10.1590/0037-8682-00382018

Susanti, K. N., \& Azam, M. (2016). Relationship between BCG vaccination status, contact history and personal hygiene with leprosy in Pekalongan City. Unnes Journal of Public Health, 5(2), 130-139.

Tarmisi, A., Arifuddin, A., \& Herawanto. (2016). Risk analysis for high endemics in the Hot Water Village, West Parigi District, Parigi Moutong Regency. Jurnal Kesehatan Tadulako, 2(1), 23-33.

Thakkar, S., \& Patel, S. (2014). Clinical profile of leprosy patients: a prospective study. Indian Journal of Dermatology, 59(2), 158-162. https://doi.org/10.4103/0019-5154.127676

WHO. (2016). Transmission of leprosy. Geneva: World Health Organization.

WHO. (2017). Report on BCG vaccine use for protection against mycobacterial infections including tuberculosis, leprosy, and other nontuberculous mycobacteria (NTM) infections. Geneva. World Health Organization.

Wicaksono, M. A., Faisya, H. A. F., \& Budi, I. S. (2015). Relationship between the physical environment of the house and the characteristics of respondents with the incidence of clinical leprosy in Bandar Lampung City in 2015. Jurnal Kesehatan Masyarakat, 6(3), 167-177.

Yuniarsari, Y. (2014). Risk factors associated with leprosy. Unnes Journal of Public Health, 3(1), 1-10. 